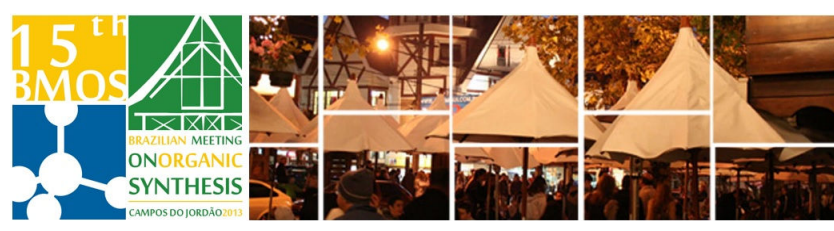

\title{
Studies toward the first total synthesis of Floribundane B
}

\author{
João V. S. Silva, Inês Resck (PQ), Angelo H. de L. Machado (PQ)* \\ Campus Universitário Darcy Ribeiro, 4478, CEP 70904-970, Asa Norte, Brasília-DF \\ *nagelo@unb.br:
}

Keywords: Floribundane B, total synthesis, lactones

\section{INTRODUCTION}

Floribundane $\mathrm{A}$ and Floribundane $\mathrm{B}$ are new iridoids recently isolated by de Mendoça and coworkers from barks and trunks of Hymenodictyon floribundum B. L. Rob. The trunk has been used on Angola's folk medicine for the treatment of fever ${ }^{1}$.

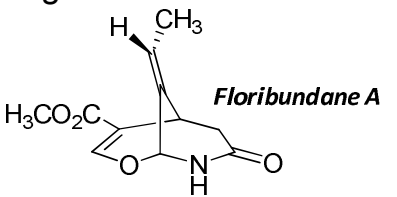<smiles>C/C=C1/C(=O)OCCC1CCO</smiles>

Figure 1. Structures of Floribundane $A$ and $B$.

Due to our interest to synthesize new lactones with promising biological activities and the absence of a total synthesis of this molecule, we started synthetic studies aiming the total synthesis of Floribundane B. Our retrosynthetic analysis has the hydroxylactone 1 as the key intermediate and this abstract reports our former results.<smiles>C/C=C1/C(=O)OCCC1CCO</smiles><smiles>C=CC(C)C</smiles>

Floribundane $B$<smiles>CC(O)C1=CCCOC1=O</smiles>

1
Scheme 1. Retrosynthetic analysis for Floribundane B.

\section{RESULTS AND DISCUSSION}

The Baylis-Hillman's adduct 3 was obtained in 95\% yield, and this result is in according to the literature ${ }^{2}$. The adduct 3 was submitted to hydrolysis to affords the acid $\mathbf{4}$ in yields higher than $90 \%$.

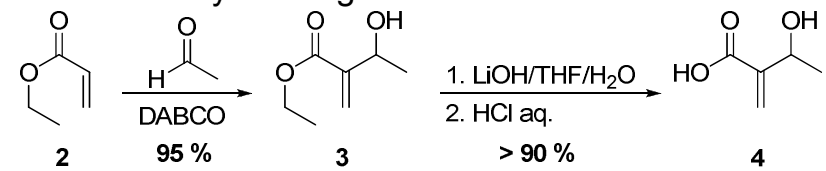

Scheme 2. Synthesis of intermediate 4.

Attempts to prepare the diene 5 by direct alkylation of $\mathbf{4}$ or it's activation by DCC followed by but-3-en-1. ol treatment failed. ${ }^{3}$
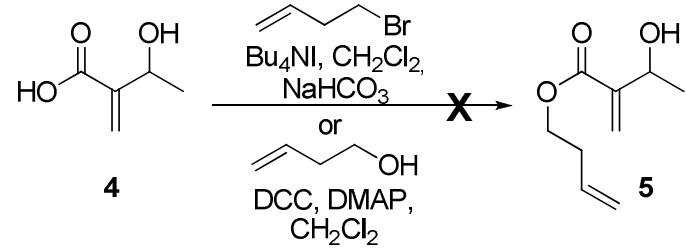

Scheme 3. Attempts to prepare diene $\mathbf{5}$.
Due to these difficulties to prepare the desired diene, a new strategy to get an equivalent diene based on Knoevenagel condensation was started.

The intermediate 7 was obtained in $80 \%$ yield from 6 and its condensation with acetaldehyde gave the desired diene 8 in only $10 \%$ yield. ${ }^{4,5}$<smiles>CC1=CC(=O)OC(C)(C)O1</smiles>

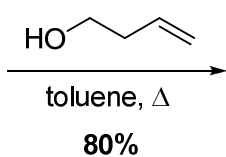

$80 \%$

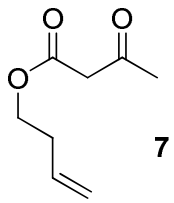

$\mathrm{N}_{\mathbf{H}} \underset{\mathbf{1 0 \%}}{\mathrm{Py}, \mathrm{EtOH}, 0^{\circ} \mathrm{C}}$<smiles>CC(=O)C1=CCCOC1=O</smiles>

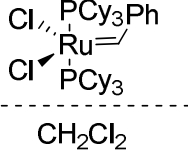

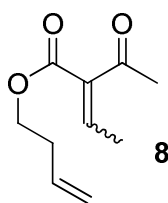

Scheme 4. New strategy to Floribundane B synthesis.

\section{CONCLUSION}

The diene 8 could be prepared in modest yield by Knoevenagel condensation of 7 and acetaldehyde. The optimization of this reaction and the ring closing metathesis to prepare the lactone $\mathbf{9}$ are ongoing in our lab and is a promising synthetic route to the first total synthesis of Floribundane B.

\section{ACKNOWLEDGEMENTS}
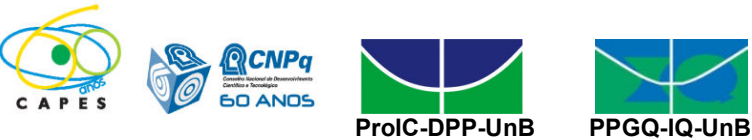

\section{REFERENCES}

[1] Borges, C. M. P.; Diakanawma, C.; de Mendonça, D. I. M. D. J. Braz Chem. Soc. 2010, 21, 1121-1125; [2] Gilbert, J. C.; Yin, J. Tetrahedron 2008, 64, 5482.; [3] Bocchi, V.; Casnati, G.; Dossena, A.; Marchelli, R. Synthesis 1979, 957.; [4] Clemens, R. J.; Hyatt, J. A. J. Org. Chem. 1985 50, 2431.: [5] a) Cope, A. C.: Hofmann, C. M. J. Am. Chem. Soc. 1941, 63 3456; b) Antonioletti, R.; Bovicelli, P.; Malancona, S. Tetrahedron 2002, 58 , 589. 